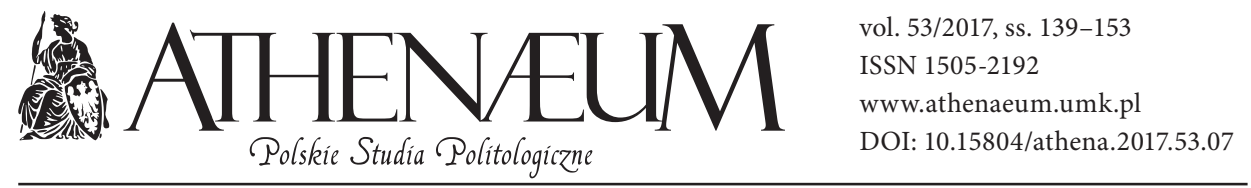

\title{
AUTORSKA AUDYCJA RADIOWA JAKO FORMA RYTUAŁU
}

\author{
AUTHOR'S RADIO BROADCAST AS A FORM OF RITUAL
}

\author{
Marek Jeziński*
}

\begin{abstract}
ABSTRAKT
Celem artykułu jest interpretacja radiowej audycji autorskiej w antropologicznych kategoriach rytuału. Zakładam, że audycja radiowa, zwłaszcza prowadzona przez charyzmatycznego i obdarzonego autorytetem dziennikarza, jest swoistym rytuałem medialnym. Jego struktura i przebieg noszą znamiona działania rytualnego, determinowanego przez specyfikę medium, w jakim do rytuału dochodzi. Działanie rytualne przebiega w kontekście mediów masowych i charakteryzuje się wielokodowością i wielością parametrów, co wynika $\mathrm{z}$ faktu, że w procesie komunikacji tworzone są kontekstowe znaczenia na linii radiowi dziennikarze-słuchacze. Kategoria rytuału medialnego zostanie $\mathrm{w}$ tekście zilustrowana przykładami z audycji autorskich prowadzonych w Programie Trzecim Polskiego Radia przez Piotra Kaczkowskiego i Marka Niedźwieckiego w latach 80. XX wieku.
\end{abstract}

Słowa kluczowe: rytuał, działania rytualne, media masowe, radio, autorska audycja radiowa
The objective of the paper is the interpretation of an author's radio broadcast in the anthropological context of ritual. I imply that radio broadcast, especially led by a charismatic journalist enjoying the authority status, can be presented as a special kind of media ritual. Its structure and course bear the features of ritual activity, determined by the specific character of the medium in which such a ritual is held. The ritual activity runs in the context of the mass media and is characterized by multi-code features and multitude of parameters, which stem from the fact that in the process of communication the contextual meanings are generated between the journalists and the radio listeners. The category of media ritual will be illustrated in the text by the examples of the selected author's broadcasts led by Piotr Kaczkowski and Marek Niedźwiecki held in the Programme Three of the Polish Radio in the Eighties of the $20^{\text {th }}$ century.

Keywords: ritual, ritual activities, mass media, radio, the author's broadcast

* Uniwersytet Mikołaja Kopernika w Toruniu, Wydział Politologii i Studiów Międzynarodowych. 
Radio jest specyficznym nośnikiem przekazu, w którym istota komunikowania często jest ograniczona do jednego wymiaru: nadawca posługuje się głosem, by zaabsorbować zmysł słuchu odbiorcy, a kanały komunikacyjne związane są z koncentracją na takim właśnie sposobie komunikowania. Ten szczególny aspekt związany z nadawcą komunikatu nie oznacza, że sytuacja odbioru ogranicza się jedynie do jednego zmysłu: słuchacz, będąc czynnym uczestnikiem aktu komunikacji, może angażować się z powodzeniem w różnorodne czynności, wykorzystujące w aktywny sposób inne zmysły (przykładowo, słuchając radia, odbiorca może czytać jednocześnie książkę lub gazetę, czy też przyrządzać i zjadać posiłek, co oznacza wykorzystywanie jednoczenie zmysłów słuchu, wzroku i dotyku w przypadku czytania, zaś w drugiej sytuacji - symultanicznego użycia zmysłów słuchu, wzroku, dotyku, powonienia i smaku). Zwróćmy jednak szczególną uwagę na słuch jako na prymarne źródło doświadczenia zmysłowego pozwalające odbierać przekazy dzięki medium, jakim jest radio. Medium to, ze zrozumiałych powodów, bez zmysłu słuchu nie może być odbierane - całkowity sens jego funkcjonowania zależny jest od możliwości słyszenia przekazów przez odbiorcę. Alan Beck (2007, s. 5) stwierdza w tym kontekście, że „aurality is both active, that is, the 'listening-to-ness' of radio reception (the listener's activity), and passive, the 'heard-of-ness' of broadcast performers - speaker or presenter or interviewee or play character. It is also the listening-in, in itself. Dodatkowo zaś, jak napisała Grażyna Stachyra (2010, s. 322): „ «teksty» fonowane (czyli wypowiadane przez człowieka) w radiu właśnie dzięki jedynie oralnej formie przekazu zyskują podwójny wymiar: odbiorca dekoduje je na poziomie informacyjnym oraz interpretuje brzmienie jako dodaną wartość semantyczną. System znaków dźwiękowych, jakim się radio posługuje, znajduje swoje odniesienie w rzeczywistości oraz posiada praktyczny aspekt komunikacji radiowej, specyficzny dla tego medium".

Andrew Crisell zauważa, że radio w pierwszym rzędzie odwołuje się do wyobraźni słuchacza, co sprawia, że ma ono pewną przewagę nad mediami wizualnymi (Crisell, 1994, s. 7). Jednak Crisell (1994, s. 7) stwierdza dalej, że: „since the greatest number of scenses through which any of the mass media can communicate to us is two (sight and hearing), it follows that all the media, and not just radio, will invoke the imagination to compensate for their various deficiencies". Co zrozumiałe, odbiorca zawsze wyobraża sobie sytuację, w jakiej odbywa się audycja oraz na podstawie głosu przypisuje określone atrybuty fizyczne (przede wszystkim wygląd i wyraz twarzy) i charakterystykę psychologiczną (usposobienie, podstawowe cechy charakteru) osobie mówiącej na antenie 
radiowej. Dziennikarz jako osoba prezentująca muzykę, wiadomości, sprawozdanie sportowe, relację z giełdy finansowej itd. przestaje dla słuchacza być jedynie głosem, a zaczyna - dzięki wyobraźni - funkcjonować jako konkretna osoba wyposażona w określone cechy charakteru i wygląd fizyczny.

Celem niniejszego artykułu jest pokazanie, że audycja autorska, zwłaszcza prowadzona przez charyzmatycznego i obdarzonego autorytetem dziennikarza, jest swoistym rytuałem medialnym. Działanie rytualne i sam rytuał, jako jedno $\mathrm{z}$ najważniejszych pojęć $\mathrm{w}$ antropologii, są adaptowane do potrzeb funkcjonowania mediów masowych, stając się specyficzną formą kontaktu dziennikarza z kręgiem odbiorców. Zakładam, że rytuał radiowy jest swoistym rodzajem działania rytualnego, bowiem jego struktura i przebieg są determinowane przez specyfikę kontaktu między nadawcą i głównym aktorem a odbiorcą działań. Kontakt ten zapośredniczony jest w przypadku radia przez medium masowe, co sprawia, że rytualność musi być rozumiana jako element funkcjonujący w kontekście aktu komunikacyjnego. Kategoria rytuału medialnego zostanie w tekście zilustrowana przykładami z audycji autorskich prowadzonych w Programie Trzecim Polskiego Radia przez Piotra Kaczkowskiego i Marka Niedźwieckiego w latach 80. XX wieku.

\section{NOTA METODOLOGICZNA}

Badanie przekazów medialnych w kontekście rytuału wymaga podejścia metodologicznego, które powinno łączyć kilka aspektów składających się na studium przypadku, jakim jest audycja radiowa. Najistotniejsze z nich obejmują analizę treści, wyrastającą ze studiów kulturowych, analizę krytyczną mediów oraz antropologiczne podejście do struktury rytuałów. Każdy z tych aspektów ma poświęconą mu literaturę przedmiotu (por. choćby: Rapley, 2010; Angrosino, 2010; Fiske, 2010; Taylor, Willis, 2006; Barker, 2005). Co więcej, jak wykazuje w swoim dziele Robert Koziniets (2012), badanie mediów, w tym nowych mediów, może przybrać charakter etnograficzny, uzupełniany w razie potrzeb dodatkowymi technikami.

Oznacza to, że obserwacja rytuału medialnego musi łączyć podejścia pochodzące $\mathrm{z}$ różnych obszarów, co wynika $\mathrm{z}$ faktu, że audycja radiowa to działanie komunikacyjne charakteryzujące się wielokodowością i wielością parametrów (często trudnych do jednoznacznej i precyzyjnej operacjonalizacji, bowiem trudno uchwytnych w badaniu). Najważniejsza kwestia dotyczy faktu, że istotne znaczenia w procesie komunikacji są tworzone poprzez kontekstowość działania 
na linii nadawca-treść przekazu- medium-odbiorca. Rytuał, jakim jest autorska audycja radiowa, to efekt tworzenia znaczeń w praktyce użytkowania mediów, a więc z konieczności etnograficzne badanie praktyk znaczących.

\section{RYTUAŁY W ŻYCIU SPOŁECZNYM}

Specyficzne warunki aktu komunikacji, w jakim przebiega zazwyczaj cykliczna audycja radiowa, sprawiają, że o programach takich (większości z nich) mówić można jako o rytuale odbywającym się w mediach masowych. Sam rytuał zdefiniujmy jako czynność odbywającą się według określonego scenariusza, mającą wywołać w uczestnikach poczucie przynależności do wspólnoty i wytworzenie stanu communitas. W przypadku komunikacji za pomocą mediów masowych, a w interesującym mnie przypadku - radia, ów stan to pojawienie się poczucia przynależności do danej grupy, utożsamianie się z jej wartościami i potwierdzanie owej przynależności poprzez odsłuchiwanie audycji radiowej i podzielania wartości w niej promowanych (podzielanie upodobań estetycznych w zakresie emitowanej w audycji muzyki i wykonawców). Rytuał definiować można na wiele sposobów, podkreślając różnorodne aspekty czynności wykonywanych w rytuałach (zob. na ten temat m.in. Rappaport, 2007). Przykładowo, za Bobbym Aleksandrem (Bowie, 2008, s. 151) możemy przyjąć, że „rytuał zdefiniowany za pomocą ogólnych i podstawowych pojęć jest przedstawieniem, zaplanowanym lub improwizowanym, który prowadzi do przejścia od codziennego życia do odmiennego kontekstu, w którego obrębie codzienność ulega transformacji”.

Z punktu widzenia przyjętego w niniejszych rozważaniach warto przytoczyć definicję autorstwa Stanley’a Tambiaha (Bowie, 2008, s. 153), ujmującego rytuał w kategoriach komunikacyjnych: „rytuał to kulturowo skonstruowany system symbolicznej komunikacji. Składa się z ułożonych we wzory i uporządkowanych sekwencji słów i działań, często wyrażanych przy użyciu wielorakich środków, których zawartość i ustawienie charakteryzują się różnym stopniem formalności (konwencjonalności), stereotypowości (sztywności), kondensacji (stopienia się) i redundancji (powtórzenia)".

Mówiąc o rytualnym aspekcie audycji radiowej, można przyjąć, że jest to typ działania rytualnego odpowiadającego - wyróżnionej przez Catherine Bell (1997, s. 94) - kategorii rytuałów wymiany i komunii: audycja to akt symbolicznej wymiany komunikacyjnej, mający w założeniu doprowadzić do tworzenia pewnej wspólnoty. Ten ostatni aspekt należy podkreślić szczególnie mocno, bowiem 
poprzez kreowanie kręgu odbiorców zaznacza się oddziaływanie autorytetu medialnego na odbiorcę. Bell zwraca uwagę na jeszcze jedną kwestię, związaną z badaniem rytuału jako elementu życia społecznego (Bell, 1997, s. 89): „rytuał jako wyraz paradygmatycznych wartości śmierci i odradzania się; rytuał jako mechanizm wciągający jednostkę do społeczności i ustanawiający społeczną całość; rytuał jako proces społecznej transformacji, służący catharsis, ucieleśnianiu symbolicznych wartości, definiowaniu natury rzeczywistości czy też walki o kontrolowanie znaków".

Wyszczególnione powyżej aspekty odnieść trzeba do audycji radiowej w interesującym mnie w pracy kontekście. W tej właśnie perspektywie audycja „wciąga jednostkę do społeczności”, „ucieleśnia symboliczne wartości” oraz jest narzędziem „walki o kontrolowanie znaków”. Inaczej mówiąc, w tym kontekście radio to sposób na produkowanie, podtrzymywanie i kontrolowanie definicji sytuacji: media i kultura popularna to teren kulturowych sporów, na którym udzielamy legitymizacji zawartości mediów lub też nie udzielamy jej, próbując promować alternatywne definicje sytuacji i wartości nieprzystające do aktualnie promowanych, zwłaszcza w odniesieniu do mediów mainstreamowych.

Za niezwykle istotny element każdego niemal rytuału uznać należy jego część określaną w antropologii mianem communitas, funkcjonującą jako ostatni element całości działań rytualnych. Jest to swoisty rodzaj wspólnoty w danej grupie ludzkiej, osiągany w procesach rytualnych. Występuje on jako konsekwencja wspólnych działań członków danej społeczności i jako charakteryzujący się szczególnymi relacjami grupowymi (szczególnymi, bowiem niewystępującymi w „naturalnym”/,normalnym” biegu życia społeczności) odróżniany jest przez Victora Turnera (2010) od „obszaru wspólnego życia”. Turner (2010) zakłada, że typowy dla każdego społeczeństwa system hierarchiczny, w którym zachodzi działanie rytualne i w konsekwencji dochodzi do tej właśnie fazy rytuału zazwyczaj zostaje zaburzony i czasowo podważony przez communitas: podczas tego segmentu działań członkowie klas wyższych i niższych mieszają się, nie przywiązują wagi do różnic społecznych wynikających z różnic statusów, podzielając jednorodną definicję sytuacji. Communitas to stan charakteryzujący się zawieszeniem sztywnej struktury obowiązującej w konkretnej społeczności, jest ono spontaniczne i bezpośrednie (jak na przykład uczestniczenie w koncercie rockowym czy wspólne celebrowanie bramki zdobytej podczas meczu piłkarskiego). Zrównanie statusów jednostek ma zawsze charakter krótkotrwały i jest powodowane szczególnymi względami społecznej natury. Szczególny charakter wspólnoty stanowi zazwyczaj ostatni akt działań rytualnych, po którym 
zostaje odtworzona hierarchia społeczna i wraca do stanu sprzed rytuału, zaś zmiana może być obserwowalna w przypadku jednostek, które przeszły rytuały inicjacyjne.

Przypomnijmy krótko, że według opracowań antropologii społecznej rytuały cechuje swoista trójfazowość, na którą - jak pisze Victor Turner (2010) składają się: wyłączenie, marginalizacja (nazywana fazą liminalną) i ponowne włączenie. Etap pierwszy zakłada oddzielenie jednostki lub jednostek od normalnego, codziennego biegu życia i struktur społecznych, a więc dosłownie rozumiane wyłączenie osoby poddawanej inicjacji od zestawu zajmowanych pozycji społecznych, wykonywanych ról i pełnionego statusu (jak choćby wejście do specjalnego budynku, którego ściany stanowią granicę między światem codzienności i sfery sakralnej - przykładem może być traktowany jako święty obszar świątyni). Faza druga - liminalna, graniczna, „progowa” - to okres zawieszenia pomiędzy codziennością a wejściem w sferę rytualnych działań oraz same działania podejmowane w rytuale. Towarzyszą jej zmiany w statusie ludzi poddawanych obrzędom: staje się on niejasny, niezdefiniowany. Dzieje się tak dlatego, że jednostki na czas trwania rytuału tracą dotychczasowe miejsce w strukturze społecznej, jednak nowy status i jego wyznaczniki jeszcze nie obejmują grupy poddawanej obrzędowi, a członek grupy, jak zaznacza Turner (2005, 195-196): „znajduje się pomiędzy wszystkimi możliwymi punktami klasyfikacji”. Zakończenie rytuału następuje w fazie trzeciej, w której ludzie powracają do dawnych statusów lub - jak w przypadku rytuałów przejścia - zaczynają żyć według zasad przypisanych do nowego statusu przez nich osiągniętego (przykładowo zmiana statusu grupowego jednostek wchodzących w uznany społecznie związek małżeński). Niezależnie od charakteru działań rytualnych, to grupa zawsze definiuje rytuał, pozycję jednostek i statusy wewnątrz samej grupy - oznacza to, że antropologicznie rozumiany sens rytuału ma nieodmiennie charakter grupowy.

\section{RADIOWA AUDYCJA AUTORSKA JAKO FORMA RYTUAŁU}

Przyjrzyjmy się autorskiej audycji radiowej w kontekście działań rytualnych i ról w rytualnym procesie komunikacji pełnionych przez nadawców ceremonii radiowych i ich odbiorców. Rytualność audycji radiowej jawi się jako pochodna kilku istotnych elementów, do których należą: (1) działania rytualne i fazy 
rytuału, (2) język audycji oraz (3) role przyjmowane przez nadawcę w procesie rytualnym.

\section{Działania rytualne i fazy rytuału}

Poruszone wyżej kwestie są istotne w kontekście funkcjonowania rytuałów w mediach: audycja w radio czy telewizji jest specyficzną formą rytualnego zachowania się ludzi, w której nie można mówić o ściśle wyodrębnionych fazach działania rytualnego. Trójfazowy podział może dotyczyć słuchacza i dziennikarza radiowego, jednak nie jest on warunkiem koniecznym w sytuacji nadawczo-odbiorczej. Odnosić się on może jedynie do grania poszczególnych ról w procesie komunikowania, a więc dla każdej z ról nadawcy i odbiorcy można wyszczególnić etapy rytualnych zachowań. W fazie pierwszej dziennikarz przygotowuje się do audycji, przebywa w redakcji i studio radiowym przed wejściem na antenę, $\mathrm{w}$ fazie drugiej prowadzi audycję $\mathrm{w}$ wytłumionym akustycznie studio, będąc oddzielonym od świata zewnętrznego (w studio panować muszą odpowiednie warunki, w których przebiega praca). Faza ostatnia, powrotu do typowych ról społecznych, ma charakter związany $\mathrm{z}$ wykonywaniem zawodu dziennikarza - prezenter na ogół ma do wykonania inne redakcyjne obowiązki, wynikające ze specyfiki zawodu. Oznacza to, że zaistnienie communitas nie jest koniecznym elementem do odbycia skutecznego rytuału medialnego. Widać tu różnice między rytuałem społecznym a medialnym - będącym w tym ujęciu częścią pracy zawodowej dziennikarza radiowego i jego profesjonalnego rzemiosła.

Podejście nastawione na wykonywanie czynności rytualnych w przypadku audycji radiowej może charakteryzować także odbiorcę, jednak nie jest warunkiem koniecznym do brania udziału w rytualnych działaniach. Odbiorca bowiem może nie poświęcać uwagi i energii na słuchanie audycji i traktować ją jedynie jako „wypełniacz” czasu - włączone radio nadaje program w tle, niezależnie od zachowań słuchacza, który może w tym czasie zajmować się wieloma działaniami niezwiązanymi z odbiorem samego programu radiowego. Jeżeli jednak słuchacz traktować zechce audycję jak działanie rytualne, będzie odbywał kolejne fazy rytualnego podejścia do audycji:

- po pierwsze, wyłączenie z biegu „normalnych” spraw (włączenie radia, zajęcie odpowiedniej pozycji przy odbiorniku, przygotowanie się men- 
talne do audycji, nastawienie psychiczne, oczekiwanie na rozpoczęcie programu);

- po drugie, uważne słuchanie audycji, a więc zajęcie postawy przez odbiorcę medialnego komunikatu;

- w fazie ostatniej: powrót do pełnionych przed rytuałem ról (zajęcie się innymi obowiązkami, wyłączenie radia itd.).

Zwróćmy uwagę, że podobnie jak w przypadku nadawcy faza communitas nie jest elementem, którego obecność jest warunkiem koniecznym obycia rytuału może on nie występować, gdyż rytuał medialny mieć będzie inną strukturę niż działanie związane $\mathrm{z}$ występowaniem relacji nadawca-odbiorca, co związane jest $\mathrm{z}$ kwestią specyfiki komunikowania masowego, a więc $\mathrm{w}$ tym konkretnym przypadku programu radiowego.

Jak zaznaczono, istotną różnicą będzie tu sama faza communitas - w typowym działaniu rytualnym jest ona efektem wspólnego przebywania grupy ludzi w czasie i przestrzeni, a więc jest rezultatem działania wspólnotowego, czyli z definicji społecznego. Bez tego warunku nie ma możliwości wytworzenia się wspólnoty, a mówiąc językiem komunikologii, jest ono wynikiem specyficznej kontekstowej sytuacji, w której dochodzi do sprzężenia zwrotnego prowadzącego do silnej identyfikacji jednostek z grupą i wyznawanym przez ową zbiorowość katalogiem wartości. W przypadku mediów masowych sprzężenie zwrotne, rozumiane jako doświadczenie o wspólnotowym charakterze, niejako z definicji nie jest możliwe - nadawca komunikatów i ich odbiorca nie przebywają w tej samej przestrzeni i mamy do czynienia $\mathrm{z}$ utożsamianiem się z wartościami promowanymi w audycji, odczuwaniem wspólnoty z nadawcą-dziennikarzem i innymi osobami.

Wróćmy do kwestii traktowania audycji radiowej jako działania rytualnego. Elementy, jakie składają się na rytualność audycji radiowej, możemy zidentyfikować $\mathrm{z}$ następującymi działaniami podejmowanymi ze strony prezentera, stacji radiowej jako medium oraz odbiorcy, który poprzez własną aktywność jawi się jako element docelowy aktu komunikacji, a jednocześnie jest tym ogniwem w akcie komunikacji, które ma możliwość podejmowania działań na rzecz tworzenia specyficznej formy communitas - wspólnoty wykraczającej poza czas nadawania audycji w medium:

a) rytuał, jakim jest sama audycja: stała pora, tytuł, jingiel specyficzny dla danej audycji, powitanie - mają dać słuchaczowi poczucie wyjątkowości danej chwili, audycji, na co składa się też obecność prezentera, konkretne stałe parametry audycji (a więc jej cykliczne elementy, jak wiadomości, 
aktualności, komentarze, stałe pasmo czasowe dla konkretnego wykonawcy lub typu muzyki, wywiady). Odbiorca „wchodzi” niejako w pewien świat, uczestniczy w nim i na dwie lub trzy godziny trwania audycji poddawany jest oddziaływaniu danego prezentera. Tym samym, na tak pojęty rytualny aspekt audycji autorskiej składają się: czas programu, struktura audycji i miejsce, w którym jest ona nadawana, co sprawia, że traktować można każdą z audycji jako swego rodzaju osobną jednostkę rytualną, o quasi-sakralnym charakterze.

b) Czas nadawania programu. W każdej stacji radiowej jest on wyznaczany ramówką danego programu, przykładowo w Polskim Radio (w tym $\mathrm{w}$ Programie Trzecim) to sygnał pełnej godziny, wyznaczający rytm niemal wszystkich audycji, po nim następował krótki serwis informacyjny i kolejne audycje (jak choćby audycje autorskie: „Radiomann”, „Markomania”, „Powtórka z rozrywki”, „Mini Max”, „Lista Przebojów Programu Trzeciego”, sobotnie wydanie „Zapraszamy do Trójki”, czy też powieści w odcinkach i słuchowiska kierowane do różnorodnej publiczności);

c) Struktura audycji - budowa audycji zależna jest na ogół od ramówki przyjętej przez wydawcę i nadawcę, a więc osoby decydujące o charakterze całej stacji radiowej: w stacjach publicznych istotny jest w tym kontekście czynnik polityczny - tak też było, co zrozumiałe, w okresie lat 80. XX wieku w PRL, z którego pochodzą przykłady w tekście.

$\mathrm{Na}$ ów fabularny schemat każdego programu składają się:

- początek: sygnał godziny, jingiel charakterystyczny dla danej audycji plus powitanie zazwyczaj w jednolitej formie/formule;

- rozwinięcie audycji, które obejmuje improwizowane na bieżąco prezentacje czy rozmowy oraz stałe elementy audycji, a więc tematyczne „kąciki”: w sobotnich popołudniowych audycjach Piotra Kaczkowskiego były to choćby „Kuźnia” (fragment audycji poświęcony zespołom grającym ciężkiego rocka i heavy metal), „Zapytaj ojca, zapytaj matki” (prezentowano w tym fragmencie nagania grup z lat 60. XX wieku), czy też „Torba listonosza” (prowadzący czytał listy od słuchaczy, komentował zawarte w nich uwagi i odpowiadał na nie); z kolei w latach 80. w „Liście Przebojów Trójki” rytualnym aspektem strukturalnym było (i jest nadal) odczytywanie piosenek z kolejnych pozycji, podsumowania poszczególnych dziesiątek zaprezentowanych $\mathrm{w}$ danym wydaniu (zazwyczaj prezentowane były one na tle instrumentalnej wersji przeboju grupy ABC „The Look of Love”; dodajmy, 
że prowadzący starał się zwiększać napięcie emocjonalne związane $\mathrm{z}$ prezentowaniem piosenek zajmujących najwyższe pozycje $\mathrm{w}$ danym wydaniu listy ${ }^{1}$ ), „nowości na Liście” - poprzedzane jinglem wyedytowanym z utworu „Into the Lens” grupy Yes (z płyty „Drama” z 1980 roku), ,poczekalnia” listy przebojów (utwory, które w danym tygodniu uzyskały zbyt małą liczbę głosów, by znaleźć się w prezentowanym wydaniu), korespondencja z Amsterdamu, losowanie nagród dla słuchaczy (z udziałem „Pana Bębna” - w tej roli występował młody wówczas dziennikarz Paweł Sito); oraz

- zakończenie: słowa kierowane do słuchaczy na zakończenie programu lub zapowiedź ostatniego utworu w audycji, będąca jednocześnie pożegnaniem $\mathrm{z}$ odbiorcą - zazwyczaj po ostatnich słowach lub dźwiękach muzycznych nadawany jest sygnał mijającej zegarowej godziny, stanowiący jednocześnie wstęp do kolejnego programu.

d) Miejsce - dana stacja radiowa i konkretna audycja wyznaczały swoiste ramy odniesienia, w których poruszali się sami dziennikarze oraz ich słuchacze. Przy czym miejsce to na ogół nie jest dostępne dla zwykłego słuchacza. Jest to niejako naturalna bariera wynikająca z podziału ról: nadawca-medium-słuchacz. Miejsce nadawania audycji jest w tym kontekście centrum kreowanego w rytuale uniwersum medialnego i ośrodkiem skupienia (za taki uznać można choćby adres rozgłośni w przypadku Programu Trzeciego jest to ulica Myśliwiecka w Warszawie). Miejsce jest istotne także w kontekście aktu komunikacji i sprzężenia zwrotnego między nadawcą-dziennikarzem a słuchaczem: w dobie mediów tradycyjnych na konkretny adres rozgłośni słuchacze przysyłali listy do danego dziennikarza, podobnie - na podany adres przysyłano kartki pocztowe z głosami na piosenki w Liście Przebojów Trójki.

1 W pierwszej połowie funkcjonowania Listy Przebojów 3 owo „dawkowanie emocji” miało istotne znaczenie w kontekście swoistej symbolicznej rywalizacji polskich zespołów i ich fanów (często zrzeszonych w fankluby). I tak: Maanam rywalizował z Perfectem, Perfect z Republiką, a Republika z Lady Pank. Pamiętać przy tym należy, że dla ówczesnej młodzieży pozbawionej dostępu do realnie funkcjonującego rynku muzycznego Lista Przebojów 3 była swoistą „wyrocznią” gustów i miernikiem popularności grup rockowych w Polsce. Zajęcie pierwszego miejsca na Liście, a często też samo znalezienie się w zestawieniu, było w tej perspektywie znaczącym symbolicznym osiągnięciem, pociągającym za sobą oznaki uznania społecznego oraz większą frekwencję na koncertach. 


\section{Język rytuału}

Działania rytualne, o których mowa, sprzyjały tworzeniu hermetycznego języka, zachowań rozpoznawalnych jedynie przez wtajemniczonych. Jako przykład ilustrujący tę kwestię podam sposób kreowania osobowości dziennikarskiej prezentowany przez Piotra Kaczkowskiego, który kontakt ze słuchaczami opiera na kompetencjach zawodowych, sprofilowanej muzyce prezentowanej w radiu oraz na specyficznym języku, którym dziennikarz posługiwał się w latach 80 . w programach, takich jak „Mini Max”, sobotnich programach popołudniowych "Zapraszamy do Trójki” i audycjach nocnych. Słowo używane przez Kaczkowskiego było słowem komentującym i interpretującym to, co zawarte było w utworach, dotykało emocji, wrażeń osobistych i wkraczało w sferę intymności. Bardzo interesującym przykładem są zabiegi mające na celu wytworzenie własnego języka w audycjach prowadzonych przez Kaczkowskiego.

Przykładem takiego rytualnego podejścia do mediów była „Lista przebojów greckich” prezentowana w sobotnich popołudniowych wydaniach „Zapraszamy do Trójki” przez Piotra Kaczkowskiego: piosenki nie funkcjonowały pod oryginalnymi tytułami nadanymi im przez wykonawców, ale miały tytuły nadane im przez prowadzącego audycję - były nimi kolejne litery greckiego alfabetu. Utwory pochodziły z repertuaru zespołów relatywnie nieznanych, co nadawało całej radiowej zabawie w grecki alfabet rysu hermetyczności, tajemniczości i tajnego charakteru. W konsekwencji utwory takie jak, przykładowo: „Pandora” („Gamma”) Cocteau Twins (dodać warto, że piosenka ta pojawiła się na LP3 pod oficjalnym tytułem, co w pewnym sensie zniweczyło starania Kaczkowskiego o zachowanie tajemnicy, jednak z drugiej strony nieznana szerzej szkocka grupa Cocteau Twins niespodziewanie zyskała dużą popularność w kręgach polskiej młodzieży interesującej się indie rockiem), „Musica Eterna” („Delta”) Dead Can Dance, „Over Zoom” („Alfa”) The Startled Insects, „Everybody’s Dead” („Dzeta”) Microdisney oraz „When It’s Over” („Beta”) Wipers zyskały ogólnopolską popularność dzięki kryptonimom-tytułom z alfabetu greckiego. Po wielu tygodniach prowadzący miał zwyczaj ujawniać prawdziwe tytuły i nazwy wykonawców, których utwory prezentował jako część swojej audycji.

Przypomnieć tu także wypada takie elementy językowe, jak określenie Rogera Watersa „Pan Fajans” (jeden ze słuchaczy niezadowolonych z faktu, że Kaczkowski darzy Watersa wielkim szacunkiem, określił go właśnie w ten sposób, dając wyraz własnej negatywnej ocenie twórczości byłego lidera Pink Floyd, 
dziennikarz „przejął” to wyrażenie, nadając mu w swoich audycjach pozytywnego wydźwięku), „przy takiej muzyce płot maluje się sam”, ,jazda obowiązkowa”, „dzień bez Pandory jest dniem straconym”, „,ech rzemiosł różnych”. Wszystkie te określenia odnosiły się do konkretnych utworów i wykonawców, sytuacji, o których prezenter opowiadał na antenie, tworząc atmosferę intymności i łączności nadawcy z odbiorcą. Wyrażenia te nadawały audycjom rysu niecodzienności, odmienności od tego, co prezentowane przez innych dziennikarzy. Mamy tu jednocześnie swoiste cechy społecznego użycia języka pozwalające zaliczyć go do języka tajnego o typowych funkcjach integracyjnej i ekskluzywnej, funkcjonując przy tym jako część radiowego rytuału. Język w takiej sytuacji nie tyle opisuje rzeczywistość, ile tworzy wspólnotę, naznacza jej granice i pozwala odróżnić myślących i odczuwających podobnie od tych, którzy nie podzielają danej wizji rzeczywistości. Niszowość miała kreować poczucie wyjątkowości: niezwykle popularna „Lista Przebojów Programu Trzeciego” prowadzona przez Marka Niedźwieckiego była programem dla odbiorcy masowego, o niewymagających gustach muzycznych - w opozycji do tej audycji Kaczkowski zaproponował "Listę przebojów greckich”, która była programem, z założenia, dla znacznie mniej licznej, za to wyrobionej muzycznie publiczności, która przyjmowała z entuzjazmem grę, jaką ze swoimi odbiorcami prowadził prezenter. W latach 80 . audycji Kaczkowskiego słuchano nie tylko po to, by poznawać nową muzykę, ale po to, by obcować z autorytetem medialnym, „Szamanem eteru”2. Nowa muzyka była w audycji istotna, jednak prezenter mógł prezentować różnorodne utwory (zarówno nowe, jak i już znane publiczności), a audycja cieszyła się popularnością. Odbiorcom chodziło bowiem o sposób, w jaki je prezentowano, a więc szczególny typ więzi, jaka powstawała podczas samej audycji między słuchającymi a radiowcem obdarzonym autorytetem medialnym. Tego typu sytuacja komunikacyjna możliwa była jedynie w warunkach medialnego monopolu i niepodważalnego stanowiska nadawcy informacji - w świecie kultury internetu 2.0 utrzymanie $\mathrm{w}$ tajemnicy tytułu i wykonawcy utworu, a więc zachowanie w sekrecie pewnego kodu istotnego i zrozumiałego jedynie dla grupy wtajemniczonych osób, byłoby niemożliwe ze względu na to, że wielość kanałów informacyjnych i dostęp do alternatywnych źródeł informacji sprzyja rozpowszechnianiu się danych oraz możliwości ich weryfikacji.

2 Określenie „Szaman eteru” zostało użyte jako tytuł krótkiego filmu biograficznego o Piotrze Kaczkowskim z 2000 r., wyreżyserowanego przez Jacka Sucheckiego i Pawła Wendorffa. 
Role przyjmowane przez nadawcę w procesie rytualnym

W każdym działaniu rytualnym istotnym elementem są wykonujący go ludzie, którzy mają jasno określone role do spełnienia w rytualnych działaniach:

a) Prezenter: określany też jako „mistrz ceremonii”, od jego gustu i wyborów danego dnia zależy zawartość merytoryczna konkretnego wydania audycji. Co wynika z samego charakteru audycji radiowych - prezenter pełni role kapłańskie oraz odpowiada za powodzenie i fortunność czynności rytualnych;

b) Słuchacz: zajmujący na ogół pozycję bierną, jednak w tradycyjnych mediach były dopuszczalne pewne elementy aktywności, do których należały: krótka rozmowa telefoniczna w trakcie audycji, odpowiedzi na listy, goście pojawiający się z wizytą w studio (przysłowiowi „zwykli ludzie” - w Liście Przebojów Trójki funkcjonujący pod kategorią „wycieczka”); oraz

c) Zaproszony specjalny gość audycji. Była to zazwyczaj osoba o szczególnym statusie i często zajmująca niezwyczajną społeczną pozycję, a więc człowiek z innego - poza radiowego - porządku strukturalnego. Gość udzielał wywiadu, dzielił się wrażeniami, często zapowiadał utwory. Do tego grona należeli artyści, aktorzy, pisarze czy - co najczęstsze - muzycy (egzemplifikacje stanowią goszczący w Liście Przebojów Trójki czy w sobotnich popołudniowych wydaniach „Zapraszamy do Trójki” tacy artyści, jak: Zbigniew Hołdys, Kora, Marek Jackowski, Grzegorz Ciechowski), byli to także organizatorzy koncertów/managerowie/promotorzy, jak przykładowo - Andrzej Marzec z artystycznej agencji PAGART, zapowiadający zbliżające się koncerty Leonarda Cohena w Polsce (w 1985 roku), będące wielkim artystycznym wydarzeniem tego okresu.

\section{PODSUMOWANIE}

Wskazany tu rytualny charakter autorskiej audycji radiowej jest wzmacniany ponadto przez swoistość przekazu radiowego, a więc unikalność i „ulotność chwili”. W przypadku radia tradycyjnego do czynienia mieliśmy z niepowtarzalnością sytuacji nadawczo-odbiorczej, bowiem audycji można było słuchać tylko w konkretnych warunkach i w konkretnym czasie (nie były one powtarzane). Elementy te składają się na swoistość aktu komunikacyjnego w radio, a więc 
coś, co często określane jest jako „magia radia”, a konkretne audycje autorskie są niezwykle istotnym elementem w budowaniu więzi między rozgłośnią a słuchaczami. Złożone aspekty tworzenia się communitas wokól jakiegoś tytułu medialnego, podzielania określonego zespołu wartości i wynikającej z nich pewnej wizji świata składają się w niniejszym kontekście na specyfikę komunikowania $\mathrm{w}$ tradycyjnie rozumianych mediach masowych. Jak jednak zaznaczono powyżej, communitas przybiera w rytuale radiowym specyficzną formułę, inną - mówimy o tworzeniu się grupy zwolenników programu, audycji czy prezentera. Co istotne, jednostka utożsamiająca się z taką grupą nie musi mieć kontaktu fizycznego ani z prezenterem, ani z innymi członkami owej zbiorowości, a poczucie przynależności może mieć tu charakter jedynie symboliczny, pozafizyczny, a więc mówimy tu o fenomenie zwanym publicznością danego medium, audycji czy konkretnego dziennikarza prowadzącego cykliczne autorskie audycje.

Programy angażowały także słuchających pod względem intelektualnym i co istotniejsze $\mathrm{z}$ tego punktu widzenia - emocjonalnym. Wiedza, kompetencje zawodowe w prezentowaniu muzyki uzupełniane były emocjonalną stroną, jaka ujawniała się podczas prowadzenia radiowego programu. Dziennikarze starali się stworzyć na antenie własny świat, pokazując odpowiednie strony swojej osobowości i kierując spotkania ze słuchaczami w definiowaną przez siebie stronę, używając do tego celu swoistych i definiowanych na swój użytek rytuałów medialnych. Audycje tych dziennikarzy nosiły osobiste emocjonalne piętno, które dla słuchaczy miało istotne znaczenie w odbiorze zarówno muzyki, jak i samych słów wypowiadanych przez prezenterów. Muzyka nadawana przez nich w audycjach stawała się ośrodkiem skupienia kręgu wielbicieli danego dziennikarza, podobnie jak jego audycje czy typowe dlań rysy osobowości. Emocje, język wypowiedzi na antenie oraz muzyka prezentowana w radio stawały się elementami skupiającymi uwagę słuchaczy, którzy doceniali pracę dziennikarską, tworząc swego rodzaju wspólnoty fanów - już nie tyle muzyki, ale muzycznych audycji oraz przede wszystkim - samego dziennikarza. W konsekwencji rytuał radiowy, jakim jest audycja autorska, spełnia przede wszystkim role: integrującą i opiniotwórczą.

\section{BiBLIOGRAFIA:}

Angrosino, M. (2010). Badania etnograficzne i obserwacyjne. Kraków: Wydawnictwo Uniwersytetu Jagiellońskiego.

Barker, C. (2005). Studia kulturowe. Teoria i praktyka. Kraków: Wydawnictwo Uniwersytetu Jagiellońskiego. 
Beck, A. (2007). Is Radio Blind or Invisible? A Call for a Wider Debate on Listening-in. Pobrane z: http://wfae.proscenia.net/library/articles/beck_blindness.pdf

Bell, C. (1997). Ritual Perspectives and Dimensions. Oxford-New York: Oxford University Press.

Bowie, F. (2008). Antropologia religii. Wprowadzenie. Kraków: Wydawnictwo Uniwersytetu Jagiellońskiego.

Crisell, A. (1994). Understanding Radio. London-New York: Routledge.

Fiske, J. (2010). Zrozumieć kulturę popularną. Kraków: Wydawnictwo Uniwersytetu Jagiellońskiego.

Koziniets, R. (2012). Netnografia. Badania etnograficzne on-line. Warszawa: Wydawnictwo Naukowe PWN.

Rapley, T. (2010). Analiza konwersacji, dyskursu i dokumentów. Warszawa: Wydawnictwo Naukowe PWN.

Rappaport, R.A. (2007). Rytuat i religia w rozwoju ludzkości. Kraków: Zakład Wydawniczy Nomos.

Stachyra, G. (2010). Fonosfera - komunikowanie rzeczywistości w radiu. W: M. Graszewicz, J. Jastrzębski (red.), Teorie mediów i komunikowania, vol. 3 (s. 321-331) Wrocław: Oficyna Wydawnicza Atut.

Taylor, L., Willis, A. (2006). Medioznawstwo. Teksty, instytucje i odbiorcy. Kraków: Wydawnictwo Uniwersytetu Jagiellońskiego.

Turner, V. (2005). Gry społeczne, pola i metafory. Symboliczne działanie w społeczeństwie. Kraków: Wydawnictwo Uniwersytetu Jagiellońskiego.

Turner, V. (2010). Proces rytualny. Struktura i antystruktura. Warszawa: Państwowy Instytut Wydawniczy. 